\title{
Working/non-working status of patents granted to HEIs and NRLs in India
}

\author{
Mamta Bhardwaj* and Amandeep Sandhu
}

The era of knowledge economy has seen a transition in the business market, from the need to control raw materials towards the protection of ideas, either as tangible or non-tangible assets. These assets may be secured in the form of various intellectual property (IP) instruments such as patents, know-how or technologies. These IP instruments (patents) not only give the IP owners (patentees) a monopoly over the use of their ideas/inventions, but also mandate them to commercially exploit the same for the benefit of the population at large. While economically developed countries (like China, USA, South Korea, Japan, etc.) appreciate this fact, developing countries like India are yet to make their mark in this transition; thus it is imperative to evaluate the IP landscape of the country. It is well acknowledged that major contributors to fundamental research in any country are the higher educational institutions (HEIs) and national research laboratories (NRLs). Hence, this study evaluates the patent commercialization ecosystem of Indian HEIs (351) and NRLs (553) for the period January 2010 to December 2017, based on the working statements filed by the patentees/assignees in the prescribed Form-27 at the Indian Patent Office.

Keywords: Granted patents, higher educational institutions, knowledge economy, national research laboratories.

UNIVERSITIES and higher educational institutions (HEIs) are the two founding pillars of a nation's economy. An academic institution is deemed successful if the knowledge imparted to its students finds its way as a tangible or non-tangible property through innovation. Further, with increase in value being assigned to 'patents filed', 'patents granted', 'patents commercialized', etc. during the rankings of institutions, it has become imperative for academic institutions to shift their focus towards innovation-oriented results. Although considering only patents generation to analyse the technological advancement or innovation index of a nation may not be appropriate, countries giving more emphasis to open science and innovation are leading in technological advancement as well.

The policy-makers and intellectual think-tanks consider that the main focus of universities and HEIs in India is to publish their research instead of securing it through patents. According to the SCImago Country Ranking ${ }^{1}$ India ranks fifth in research publications, whereas it is ranked at 50th position in 'Intellectual Property Rights' $(\mathrm{IPR})^{2}$. The country has the third largest education system, after USA and China. However, the academic fraternity in India focuses mainly on imparting knowledge to students with less interest in converting that

Mamta Bhardwaj and Amandeep Sandhu are in the DST-Centre for Policy Research at Panjab University, Aruna Chandra Hall, Top Floor, Sector-14, Chandigarh 160 014, India.

*For correspondence. (e-mail: mamtab@pu.ac.in) knowledge into a commercial commodity. This scenario can be attributed to the lack of entrepreneurial system with some vital voids in governmental or institutional level policies/guidelines. Moreover, while countries like China, Singapore, Japan, USA, South Korea, Germany, Canada and Australia give equal importance to both research publications and patents generation, Indian academic institutions limit themselves mainly to research publications. However, the scenario is now changing in the country with the implementation of the National IPR Policy $^{3}$ and introduction of model guidelines on the implementation of IPR policy for academic institutions ${ }^{4}$. Recently, the Ministry of Education, Government of India (GoI) has announced a new policy on higher education ${ }^{5}$ and proposed the establishment of National Research Foundation (NRF) to enable a culture of research to permeate through universities and HEIs.

The Department of Science and Technology (DST)Centre for Policy Research (CPR; hereafter 'Centre') had earlier conducted a study on research publications and status (granted and filed) of patents of 904 institutions in India (HEIs (351) + national research laboratories (NRLs) $(553))^{6}$. Here, the study has been extended further to assess the commercialization ecosystem in Indian academic and research institutions. The Centre has compiled data on working and non-working status of patents granted to the aforementioned institutions during the last eight years (January 2010-December 2017). Figure 1 provides the break-up of 904 institutes considered in this study. 


\section{Methodology}

In continuation of the previous study by the Centre ${ }^{6}$, further research has been done on the commercialization status of patents granted to the same Indian HEIs and NRLs. The Centre had collected information regarding working and non-working status, revenue generated after commercialization, licensees, reasons mentioned for nonworking patents, etc. using the patent search engine 'Indian Patent Advanced Search System' (InPASS) from the website of the Office of the Controller General of Patents, Designs and Trade Marks ${ }^{7}$ for analysis. Figure 2 depicts flow chart for the same.

According to Section 146(2) of the Patent Act, 1970 (ref. 8), after the grant of a patent it is mandatory for the patentee to file the working (commercially exploited) statement of the patent before 31 March of every financial year. Under Section 122 of the Act, if a patentee refuses or fails to furnish information required under Section 146, he/she is punished with a fine which may be up to Rs 10 lakhs. Although till date there is no case reported of this penalty imposition. Additionally, according to Section 122(2) of the Act, if the Controller finds the information false, the patentee who is furnishing it is punished with imprisonment which may be extendable up to six months or with a fine, or with both a fine and imprisonment. This study highlights the issues related to Form-27 and working/non-working statements filed by the applicants/patentees.

\section{Results and discussion}

The data analysis carried out in the study is as follows:

- Categorization of total patents granted.

- Field-wise break-up of total patents.

- Categorization of working patents.

- Working patents in various fields.

- Reasons for patents not working.

- Recommendations.

- Conclusion.

The total number of patents granted to HEIs and NRLs (904) in India was 4159 during the period January 2010 December 2017. This includes patents granted abroad too. Out of 4159 patents, 2198 have been granted outside India, whereas 1961 patents were granted to 186 institutions in the country. The present study was conducted on these 1961 patents granted by the Indian Patent Office.

\section{Categorization of total patents granted}

The 1961 patents were granted to 186 institutions, of which $42 \%$ were NRLs, $36 \%$ HEIs and $22 \%$ belonged to 'Others' category, comprising of industries, public sector undertaking (PSU), trusts, boards, corporation, hospitals, etc. (Figure 3).
Figure 4 shows that, in 2010, a total of 473 patents were 'in force' (active patents). Out of these 473 patents, the working/non-working statement in Form-27 was filed only for 19 patents $^{9}$. Till 2012, there was an increase in the number of patents 'in force', whereas the number of patents for which Form-27 was filed was almost stagnant. After 2013, the trend of the patents for which Form-27 was being filed began to increase. The 'Natco Pharma Ltd vs Bayer Corporation' case is important in this regard $^{10}$. In 2012, the Controller General of the Indian Patent Office granted a compulsory license, to a Hyderabad-based drug-making firm Natco Pharma Ltd (hereafter 'Natco'). This was a landmark decision in the history of the Indian patent regime. In this study we found that in 2013, the number of submissions of Form-27 increased compared to the previous years (Figure 4). Moreover, in 2013, a public notice was issued by the Patent Office directing all patentees and license holders to submit Form 27 applications for each calendar year by the end of March, for the previous year. Above mentioned evidences are very crucial in the history of Indian patent ecosystem and increase in the filing of working statements can be accredited to these facts.

There is a provision in the Patents Act, 1970 (Section 84 and Section 85), that if a granted patent is not-worked after three years of its grant, any interested person can make an application for seeking compulsory license. Also, the compulsory license can be revoked under Section 85 of the Patent Act, 1970. According to Section 85, after two years of the grant of the compulsory license, any person or the Central Government can apply for revocation of the license on the ground that the invention is not being worked in the Indian territory and it is not fulfiling the public requirement in the appropriate price. For example public is not able to access the drug in sufficient amount and the price of the drug is not affordable. The decision of revocation will be taken within a year of submitting the application to the Controller General of the Indian Patent Office.

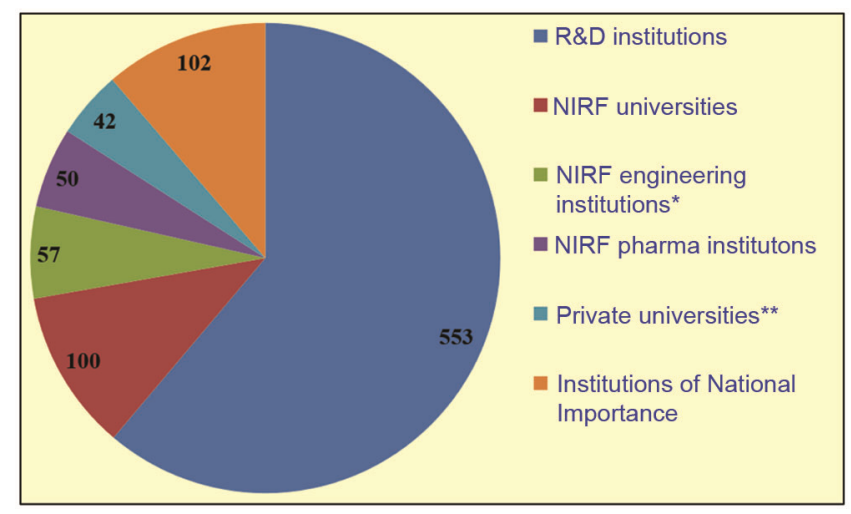

Figure 1. Break-up for 904 institutions studied. *Forty-three institutes are included in Institutions of National Importance. **Eight universities are included in the list of top 100 NIRF universities. 


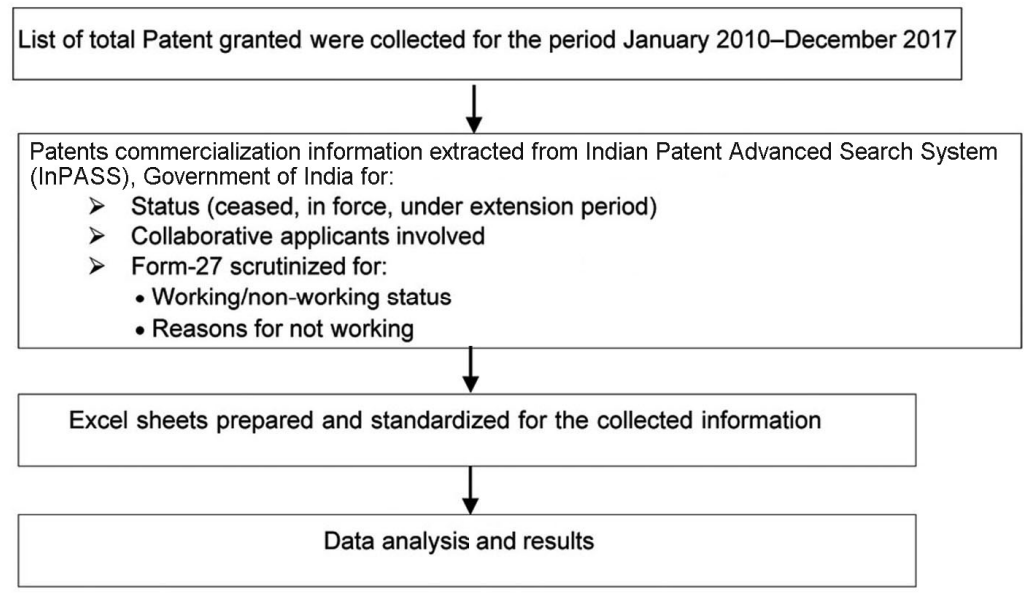

Figure 2. Flow chart for the study plan.

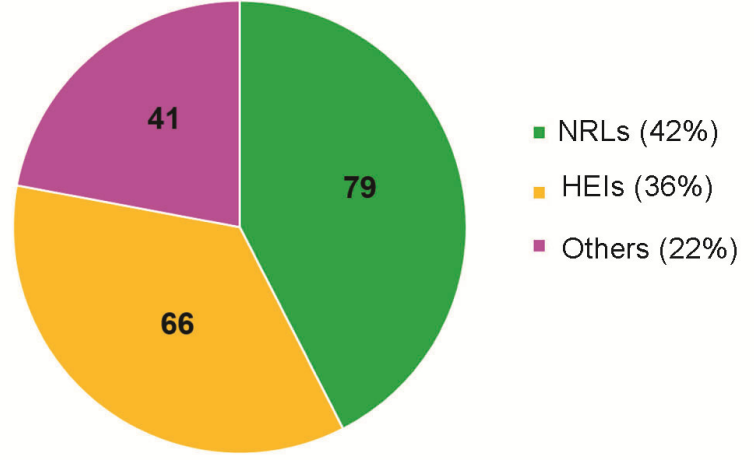

Figure 3. Categorization of institutions having patents granted. Figures inside the pie chart are the number of institutions.

\section{Highlights of the 'Natco vs Bayer' Case}

The first ever compulsory license in India was granted in 2012 to Natco (applicant for the compulsory license). An American company Bayer Corporation (hereafter 'Bayer'), which is the subsidiary company of Bayer AG, a German multinational chemical and pharmaceutical company, got a patent for a drug called 'Sofrafenib' which was used to cure advanced stage cancer in kidney and liver. In 2000, the company filed a patent cooperation treaty (PCT) application and in 2005, launched a drug with the brand name 'Nexaver'. Subsequently, in 2008, it got a patent granted for the same drug. The company started importing the drug in India and its cost was approximated at Rs 2.85 lakhs/month of therapy. The Indian company Natco approached Bayer for voluntary license to produce or sell the drug in the country by citing the high rates being charged by the latter. Firm Natco proposed to sell the same dose of the drug at Rs 8900/month of therapy, but the request was denied. In July 2011, Natco applied for the compulsory license to the Controller General of the Indian Patents Office for manufacturing a generic version of the drug 'Nexaver'. The company cited the reasons: (i) The drug is being sold at a very high price in India. (ii) The reasonable requirements of the public are not being fulfiled. (iii) Bayer had not worked the patented invention in the territory of India after three years of the grant of the patent in the country.

The Controller General accepted the request and granted the compulsory license to Natco to manufacture the drug on a non-exclusive basis. With this Natco could sell the drug for Rs 8900 for a month's therapy and pay $6 \%$ royalty to Bayer on total sales. Then Bayer appealed against the decision before the Intellectual Property Appellate Board (IPAB). The Board also ruled that the patentee (Bayer) was not able to establish the reason for not manufacturing the drug in India despite having manufacturing facilities in the country and relied only on import of the drug.

\section{Top applicants based on patents granted}

Figure 5 shows the institutions with maximum patents (granted) to their credit during 2010-17. The Council of Scientific and Industrial Research (CSIR), an autonomous and publically funded research organization, leads the chart with a total of 863 patents granted (in India only) and has a share of $44 \%$ of the total granted patents for the period 2010-17.

The Defence Research and Development Organization (DRDO), dedicated to research for the military under the Ministry of Defence, GoI is at the second position with 308 patents. The third position is occupied by an Institution of National Importance (INI), the Indian Institute of Technology (IIT) Bombay, with 76 patents granted during 2010-2017. The fourth, fifth and sixth positions are occupied by three public research organizations, while the seventh to tenth positions are occupied by academic institutions (Figure 5). Out of the total patents granted (1961), $82 \%$ share goes to these top ten applicants. Furthermore, 


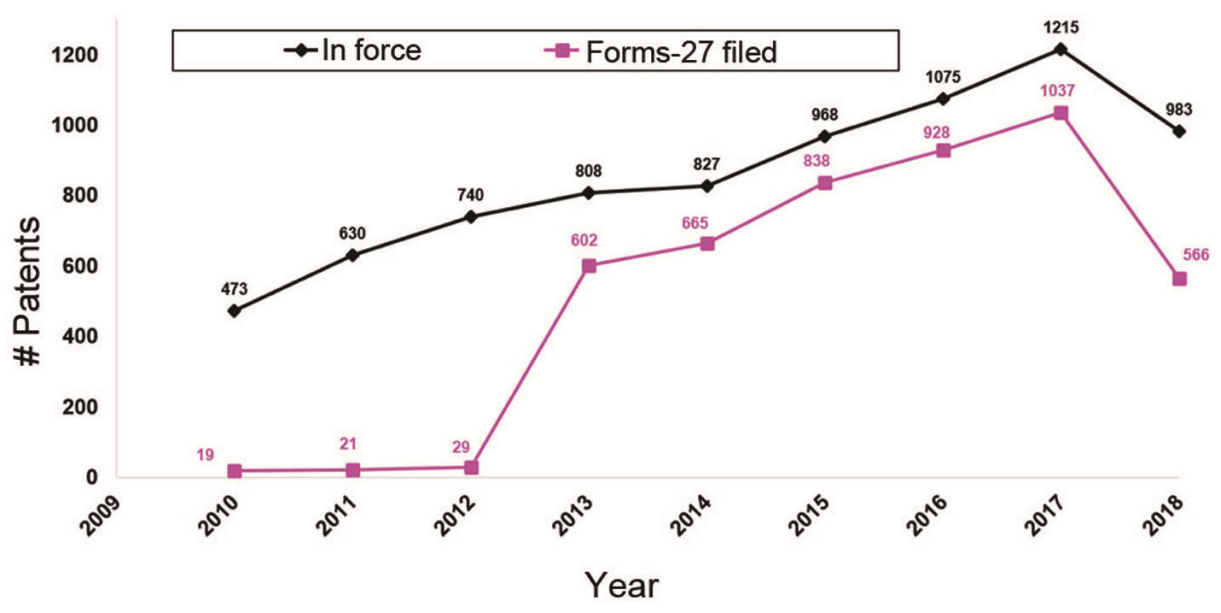

Figure 4. Yearwise trend of patents in force and for which Form-27 was filed.

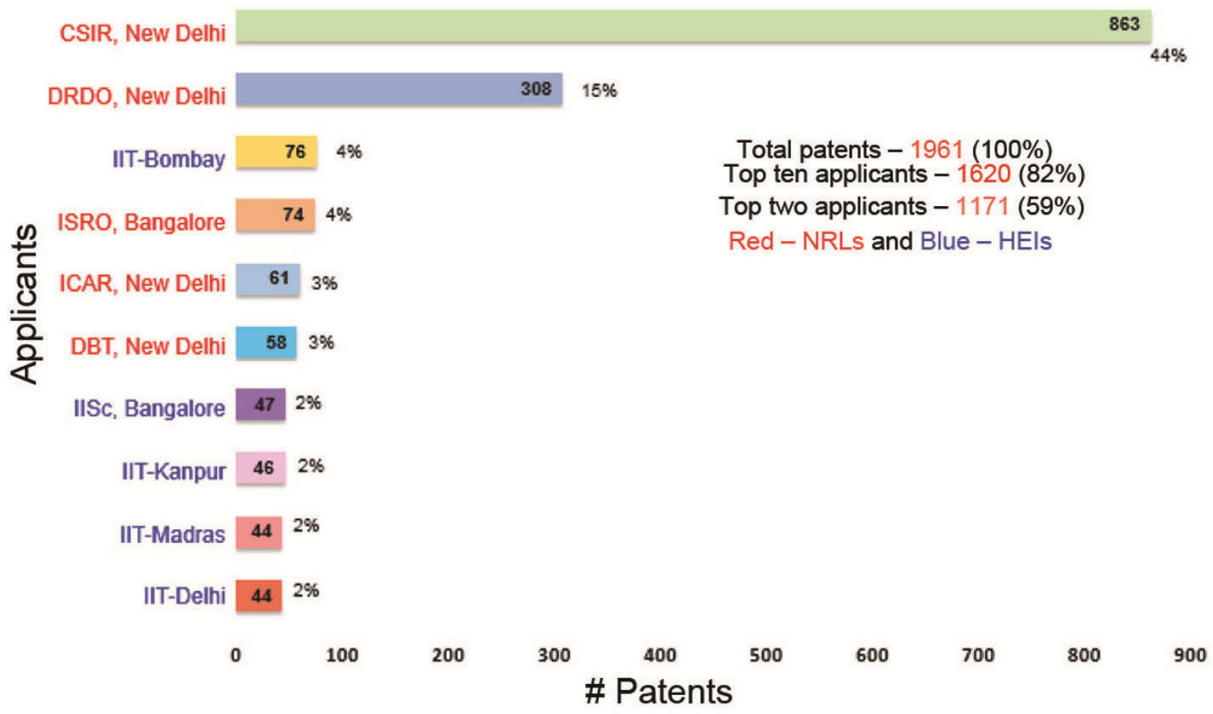

Figure 5. Top ten applicants based on total patents granted.

$59 \%$ share is contributed by only the top two applicants, i.e. CSIR and DRDO. The other major institutions having patents granted during this period are the National Institute of Pharmaceutical Education and Research (NIPER), Mohali (38); IIT, Kharagpur (23); Department of Atomic Energy (DAE), Mumbai (22); Indian Council of Medical Research (ICMR), New Delhi (19); Department of Information Technology (DIT), New Delhi (16); DST, New Delhi (15); Delhi University, New Delhi (14); Centre for Development of Advanced Computing, Thiruvananthapuram (13); All India Institute of Medical Research (AIIMS), New Delhi (11), and International Advanced Research Centre for Powder Metallurgy and New Materials, Gurugram (10). Each of the remaining applicants has less than ten granted patents and there are more than 94 applicants having single patent (granted) to their credit for the period from January 2010 to December 2017.

\section{Field-wise break-up of total patents}

The study was further extended to categorize patents field-wise, such as chemical sciences, engineering, pharma/ drugs, food/agriculture, biotechnology, physics, medical science, etc. (Figure 6). Maximum patents were granted under chemical sciences (851), followed by engineering (electronics, electrical and mechanical; 327) and pharma/ drugs (204). Only 31 patents were granted in medical science, which can be partly attributed to the fact that according to Section 3(i) of the Patents Act, 1970, 'any process for the medical, surgical, curative, prophylactic, diagnostic, therapeutic or the treatment of human being or any process for a similar treatments of animal to render them free of disease or to increase their economic value or that of their products' is not patentable in India. This Section of the Act excludes the methods of treatment 


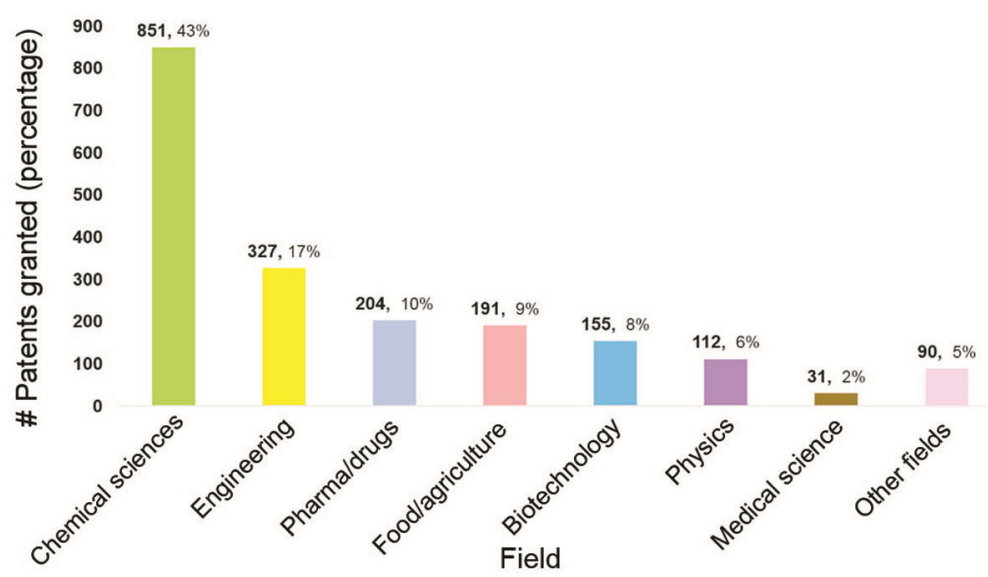

Figure 6. Field-wise break-up and percentage share of total patents granted.

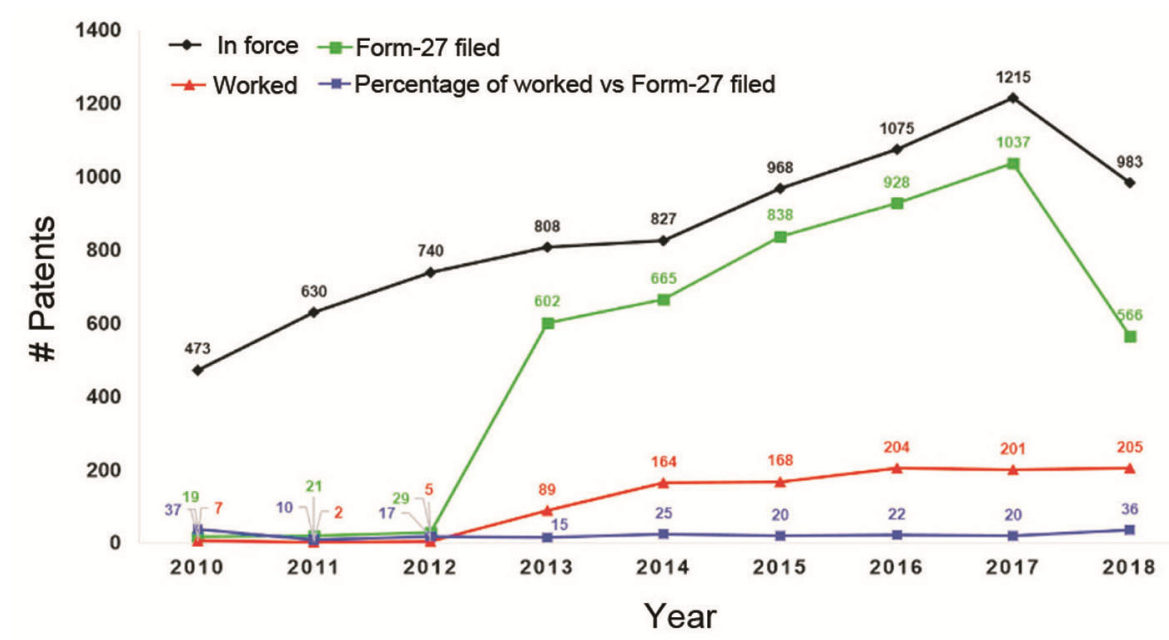

Figure 7. Yearwise trend of patents granted (in force/worked/filing of Form-27)*. *Period: information from Form-27 for the patents has been extracted for the period 2010-18.

from being patented and allows novel devices related to medical science to be patented ${ }^{11}$.

\section{Categorization of working patents}

The Patents Act, 1970 not only grants 'monopoly' to an individual or group by providing the applicant with exclusive rights on the invention, but also ensures that the invention recognized by the system must be commercialized to the fullest for the benefits of society at large. Section 146 of the Patents Act, 1970 and Rule 131 of the Patents Rules, 2016 (as amended) make it mandatory for all the patent holders to submit a commercial statement of the patent, by furnishing information regarding its working and non-working status. The present study uses this information to analyse the patents commercialization ecosystem of Indian HEIs and NRLs. Figure 7 depicts the trends from 2010 to 2018 , for indicators such as in force patents, patents for which Form-27 has been filed, working patents, etc. The statistics indicates that in 2010 the number of patents in force was 473, whereas only for 19 patents Form-27 was filed, out of which seven were marked as working patents. As shown in Figure 7, the percentage of 'worked patents' vis-á-vis 'the patents for which Form-27 was filed' is 37 (blue line). In 2011 and 2012 , the percentage of working patents was poor, but in 2013 the number of patents increased for which the working/non-working statement was filed in Form-27. However, the percentage of 'working patents' with respect to the 'patents for which the form was filed' was only 15 . The graph for the indicators 'patents in force' and 'patents for which Form-27 was filed' from 2013 to 2017 shows a gradual increase, whereas the percentage of 'working patents' with respect to 'Form-27 filed' shows very slight difference. The well-known case of 'Natco versus Bayer' made the Indian patentees take more seriously the filing of the working statement for the patents. 


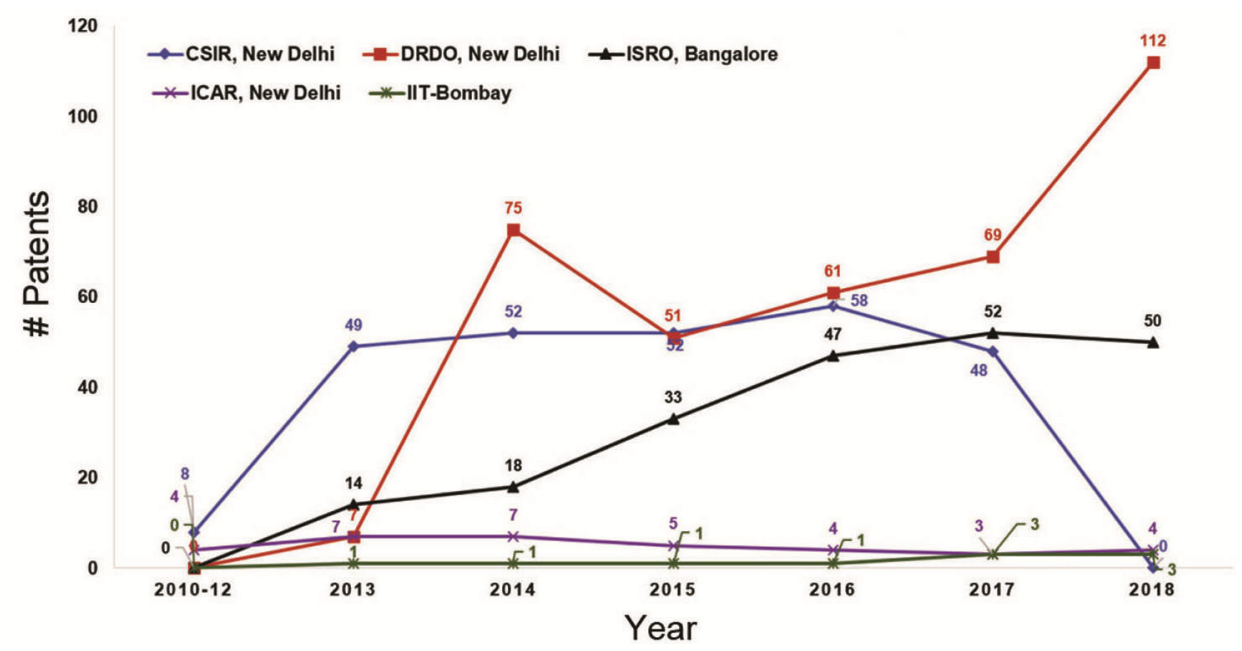

Figure 8. Yearwise number of working patents of the top five applicants.

As we can see for 2018, the graph drops for all the indicators, which can be attributed to the drop in the patents of CSIR.

Figure 8 shows the leading applicants dominating the domain of patents commercialization. The data for 2010 12 have been combined as there were only a handful of working patents. As is evident from Figure 8, out of the top five positions, four are held by research organizations (CSIR (blue); DRDO (red); Indian Space Research Organisation (black) and the Indian Council of Agricultural Research (purple)) and the fifth position is occupied by an INI, i.e. IIT-Bombay (green). The main mandate of these research organizations is to perform target-based research to generate indigenous technologies for the benefit of the masses. The research organizations securing the top positions are fulfiling their mandate effectively. For instance, DRDO has a commendable and consistent record in patents commercialization throughout the period considered for the study. CSIR also has a steady trend from 2010 to 2017 , although the graph nosedives in 2018. For CSIR, 480 patents were in force in 2017, of which 476 had filed Form-27 and further 48 of these 476 patents were marked as working, while 428 were nonworking. No form was filed for four patents. In 2018, the number of patents in force was 351, out of which Form27 was filed only for three patents which were marked as non-working. This is the reason for the drop in Form-27 filed for the year 2018, as CSIR had the maximum count of granted patents for the duration of the study.

\section{Working patents in various fields}

The working patents were further analysed on the basis of different fields mentioned earlier. In 2010-12, there were a total of 12 working patents, out of which six belonged to chemical sciences, three to biotechnology, three to food/agriculture. In 2013, maximum patents (33) were granted under chemical sciences, which was same till 2017. In 2018, maximum (59) patents were in the engineering field, whereas 57 were in chemical sciences (Figure 9). The best performing fields throughout the period from 2010 to 2018 were chemical sciences and engineering. The category 'Other fields' is related to patents of domains like transport, customer goods, games and handling, etc. The lowest working patents were in medical science.

\section{Reasons for non-working patents}

Every patentee has to file the statement of working/nonworking each year for patents which are in force, or are being maintained by paying an annuity every year till the validity of the patent. These statements are filed in the prescribed format in Form-27.

There is a section in Form-27 where the patentee or the applicant needs to mention whether the patent is working or not, and if non-working option is selected, the cause behind its non-working status and steps being taken to commercially exploit the patent need to be provided. During data extraction, it was found that most of the patentees had mentioned similar reasons for non-working of their patents (Figure 10). Some of the patentees had given inadequate and vague reasons such as 'efforts made for commercialization but unsuccessful', 'discussion in progress', 'looking for potential buyers', 'advertised in the newspaper for dissemination', 'lab-scale work', 'future R\&D required', etc. A large chunk of patentees did not even mention any reason in the form. Figure 10 depicts the yearwise details of the major reasons mentioned. Some reasons which stand out and require government intervention in order to resolve issues faced by patentees during licensing/commercialization 


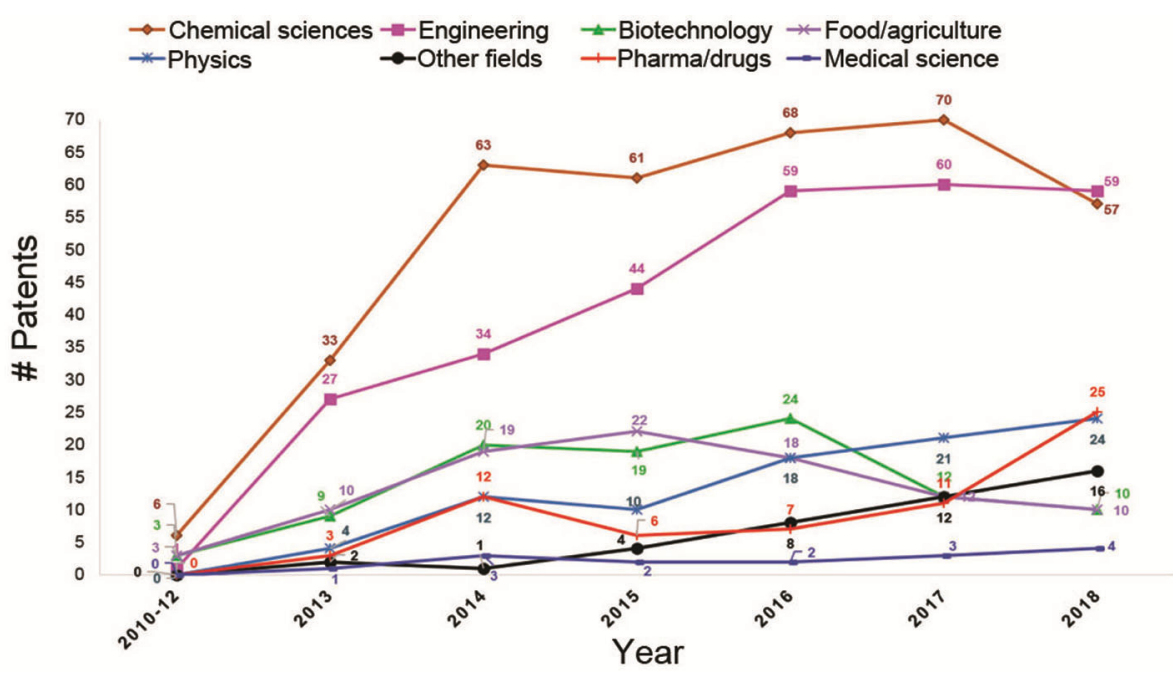

Figure 9. Yearwise break-up of working patents for various fields.

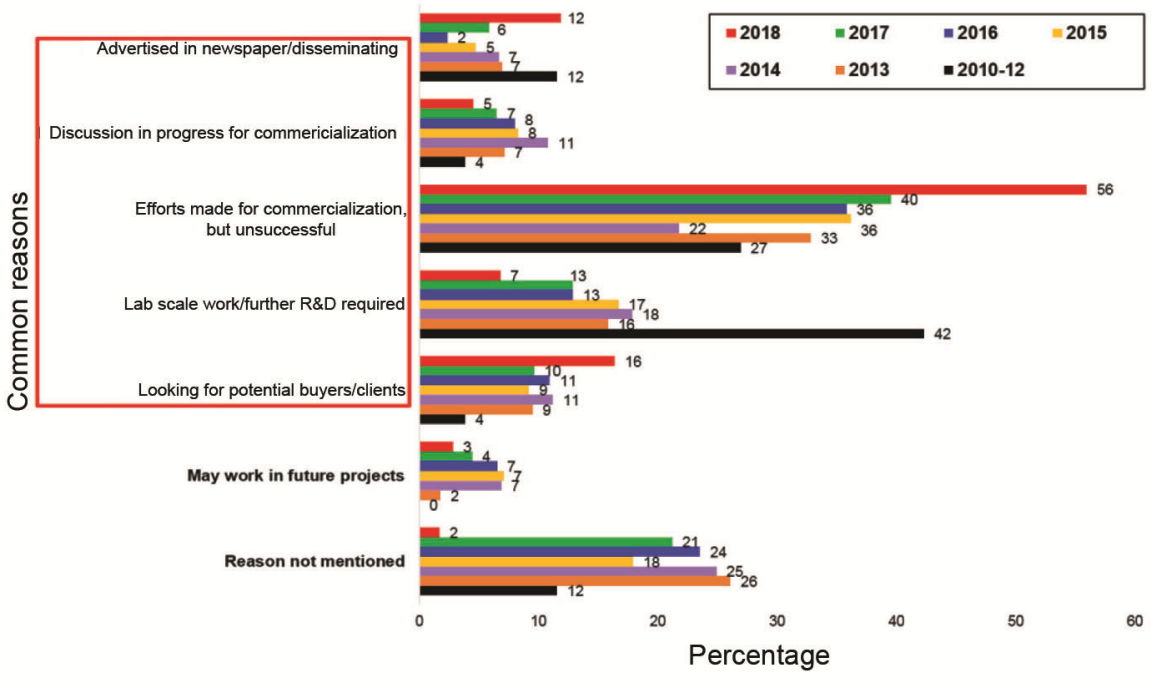

Figure 10. Common reasons mentioned in Form-27 for non-working patents.

are 'awaiting approval-transgenic material is being cleared by Genetic Engineering Appraisal Committee (GEAC)', 'Govt not taken any decision on the release of GM crops', 'Hepatitis C virus (HCV) animal model is not available in India, which is the major hindrance for testing in an animal before commercialization', etc.

\section{Recommendations}

India has all the wherewithal to compete with the leading global leaders provided it shifts focus and takes laboratory research to the market. Researchers in India are lagging behind in patents generation because approximately $70 \%$ of the patents are being filed by 'non-residents' in India $^{12}$. The study conducted by the Centre, showed that academic institutions are inclined towards publishing research ${ }^{6}$ instead of patenting their research. This can be attributed to major reasons such as lack of knowledge regarding IP issues, lacunas in existing government policies, lengthy and expensive patent-filing procedure, absence of dedicated patents commercialization cells and IPR policies in the institutions. Also, most patents are not commercialized because of the low technology readiness level, and substandard invention quality. Additionally, extra work is required to transform an invention into product coming out from HEIs and NRLs. The ecosystem in India is not amenable to licensing and commercialization because of various reasons. The low commercialization rate of patents in India can be attributed to the fact that the patent system is not conducive to convert a patent in commercial commodity in the same way as in other countries. 
Organizations like CSIR, DRDO, IIT-Delhi, IITBombay, ISRO, etc. are actively involved in both patent filing and commercialization. This can be attributed to the fact that these organizations have specialized mechanisms such as IPR policy, dedicated funds for IP activities, collaborative research with other institutions and industries, IP Cell, Entrepreneurship Cell, organizing IPR workshops, courses to sensitize students on this subject, etc. Some of the research and academic institutions have such cells in place, but they are not functioning effectively to assist researchers/students in IP-filing activities and to enhance the patents commercialization regime. Moreover, the funding criteria and disbursal of both the fraternities are different. HEIs spend funds more on infrastructure, whereas the amount sanctioned to R\&D organizations is mainly utilized for research activities. There is a need for expanding engagement of academic institutions with the industrial sector, as in joint research work, to strengthen translational research ecosystem in HEIs and R\&D institutions. However, to make Indian researchers/scientists more IPR savvy and enhance the patents commercialization ecosystem in the country, DST-CPR has come up with some recommendations.

\section{Enhancing the commercialization of patents}

- A patented invention should not go unworked just because the patentee does not have the knowledge or lacks financial resources to exploit his/her invention commercially. In order to fill this gap, the patentee should be able to entrust his/her patent to a specialized agency for its management, utilization, technology transfer or disposal as is practised by the 'Patents Trust System' in South Korea ${ }^{13}$.

- Considering the significance of the information to be furnished in Form-27, the Indian Patent Office should set up a dedicated Cell to address issues related to it. Further, the Patent Office can issue guidelines for filling Form-27 and can provide answers to frequently asked questions (FAQs) on its website. Moreover, the patentee should have the option to categorize the reasons for not working, like reasons beyond the control of the patentees, such as awaiting government clearances or regulatory issues. These can then be looked into by a dedicated Cell. There is a need to organize patent and technology fairs, where all the stakeholders working in the field of patents can come together in order to discuss their success stories and challenges so as to promote the culture of IP, such as the Patent Information Fair and Conference held in Japan.

- A compulsory license defined as 'authorizations permitting a third party to make, use, or sell a patented invention without the patent owner's consent if it is not commercialized after the 3 years of its grant', should be promoted among small and medium-sized enterprises (SMEs) and generic drug-making companies.

- A clause may be added in Form-27 to ask the patentee about specific requirements and potential industry which can take up that patent. Like the provision by the World Intellectual Property Organization for Patent Cooperation Treaty applications, wherein an applicant can highlight his/her interest in concluding licensing agreements. Form-27 can also include an option wherein the patentee can mark his/her patent for licensing or any specific requirement he/she is looking for, in order to commercialize the patent. Similarly, we can adopt from the United States Patent and Trademark Office, which provides a roadmap for applicants opting for a sale or license. Patent insurance during the process of licensing or commercialization adds credibility to the patent, since it is issued by the insuring company after a detailed study of its claims and values. It also equips the patentee in case of patent infringement. It is especially important for developing countries like India, where there are many small and emerging SMEs. The same is prevalent in USA and some European countries (including the UK, Germany, Denmark, Sweden and Finland). China has also started issuing patent insurance products since 2012 (ref. 14).

\section{Enhancing the generation of patents}

- Incentivization of individuals for successful execution of technology commercialization (BIRAC model, Gandhian Young Technological Innovation - SRISTI Awards). Similar to the National IP awards, each institution must incentivize its teaching faculty/research scholars who have generated patents/technologies (through cash awards, salary hike, financial assistance for visits to national/international events, etc.) so as to encourage and assist them in the commercialization of their patents.

- In NRLs, the cost of filing and maintenance of a patent is borne by the respective organizations. However, Ministry of Education, GoI does not offer such facilities to researchers from universities and academicians; they have to depend on the policies of their respective institutions. In order to promote IP activity in HEIs, it is suggested that Ministry of Education may create an 'IP Fund' which could be used for IP-related activities in the universities, which will also make the universities less dependent on the central government for financial assistance.

- Researchers and scientists in India are good at research, which is evident from the rank of India in research publications, but they are reluctant to convert this research into a tangible product. This can be attributed to the lack of knowledge about IP-related issues and the filing procedure. Thus researchers need to be 
educated about IP by introducing dedicated courses in their curriculum.

- In India, organizations such as CSIR, ICMR, ICAR, etc. have independent IP/technology web portals which have to be scanned individually by a scientist/ industry personnel, when searching for a particular patent/technology information, thus making the process laborious. In this regard, a national-level web portal can be designed, which provides details about all the patents (active and expired), and technologies developed by Indian scientists in order to promote collaborative research work and commercialization of patents.

\section{Conclusion}

The study complied emphasizes that patenting and commercialization of research outcomes should be recognized as a lucrative option by academic institutions. However, the trajectory of growth in patents commercialization is picking up momentum at a slower pace. It may be remarked that there is an urgent need for a shift in the mind-set of the academic fraternity, from paper publication towards patenting and then commercializing it. It also shows that Indian patentees are reluctant to file working statements of the patents granted to them. They should be made aware with the importance of filing it so that difficulty being faced by them in patents' commercialization can be addressed.

1. SCImago, SJR-SCImago Journal and Country Rank, 2018; https:// www.scimagojr.com/countryrank.php (accessed in November 2019).

2. Property Rights Alliance Report, International Property Rights Index, 2019; https://internationalpropertyrightsindex.org/countries

3. GoI, National Intellectual Property Rights Policy, Department for Promotion of Industry and Internal Trade, Government of India, 2016.

4. CIPAM, Model guidelines on implementation of IPR policy for academic institutions, Cell for IPR Promotion and Management,
New Delhi; https://dipp.gov.in/sites/default/files/Draft_Model_ Guidelines_on_Implementation_of_IPR_Policy_for_Academic_ Institutions_09092019.pdf

5. GoI, National Education Policy, Ministry of Human Resource Development, Government of India, 2020.

6. Tewari, R. and Bhardwaj, M., Mapping Patents and Research Publications of Higher Education Institutes and National R\&D Laboratories of India, ISBN 81-85322-67-8, Punjab University, Chandigarh, 2018.

7. Indian Patent Advanced Search System (InPASS); http:/ ipindiaservices.gov.in/publicsearch/ (accessed from August to October 2019).

8. Intellectual Property India, The Patents Act, 1970; http:// www.ipindia.nic.in/writereaddata/Portal/IPOAct/1_31_1_patentact-1970-11 march2015.pdf

9. Form-27, The Patent Act, 1970 and The Patent Rules, 2003, Statement regarding the working of the patented invention on commercial scale in India; http://www.ipindia.nic.in/ writereaddata/Portal/IPOFormUpload/1_39_1/form-27.pdf

10. Singhai, A. and Singhai, M., A study of Natco vs Bayer case: its effect and current situation. MIT Int. J. Pharm. Sci., 2016, 2(2), 21-23; ISSN 2394-5338 (Print); 2394-5346 (online).

11. Kankanala1, K. C., Diagnostic method patent model-patent incentives and socio-ethical concerns. J. Int. Prop. Rights, 2007, 12, 104-110.

12. Controller General of Patents, Designs and Trade Marks, Annual Report 2018-19, GoI.

13. Han, J. and Lee, H. J., A study on patent trust system in Korea. J. Intellect. Prop. Rights, 2016, 21, 27-37.

14. Sinha, R., Patent insurance: a roadmap. J Intellect. Prop. Rights, 2014, 19(6), 387-394.

ACKNOWLEDGEMENTS. We thank the Department of Science and Technology (DST), Government of India, New Delhi for financial aid to DST-CPR at Panjab University (PU), Chandigarh (grant no. DST/ PRC/CPR-03/2013). We also thank Prof. Rupinder Tewari (DST-CPR, PU) and the 'Advisory Committee' of the Centre for assisting and guiding us for fulfilling the objective of the Centre and the scientific staff of DST-CPR, PU for their continuous support during the study.

Received 30 January 2020; revised accepted 9 October 2020

doi: $10.18520 / \mathrm{cs} / \mathrm{v} 120 / \mathrm{i} 1 / 34-42$ 